\title{
Studies on Effect of Crop Regulation Practices on Physico-Chemical Attributes and Organoleptic Evaluation of Guava Variety Sardar
}

\author{
Shweta Hiremath", S.I. Athani, Archana and Kashinath Patil \\ University of Horticultural Sciences, Bagalkot, Karnataka, India \\ *Corresponding author
}

\section{A B S T R A C T}

\begin{tabular}{|l|}
\hline Ke y w o r d s \\
Guava, Crop regulation, \\
$\begin{array}{l}\text { Pruning and Bio } \\
\text { Regulators, Physico- } \\
\text { chemical attributes, } \\
\text { Organoleptic characters }\end{array}$ \\
\hline Article Info \\
\hline $\begin{array}{l}\text { Accepted: } \\
\text { 26 July 2018 } \\
\text { Available Online: } \\
\text { 10 August } 2018\end{array}$ \\
\hline
\end{tabular}

Crop regulation treatments in guava like No Pruning $\left(\mathrm{P}_{1}\right.$ - Control), Pruning $\left(\mathrm{P}_{2}\right)$ and four bio regulators namely NAA $250 \mathrm{ppm}\left(\mathrm{T}_{2}\right)$, Urea $15 \%\left(\mathrm{~T}_{3}\right)$, Ethrel 500ppm $\left(\mathrm{T}_{4}\right)$ and CCC $50 \mathrm{ppm}\left(\mathrm{T}_{5}\right)$ were used to regulate rainy season crop on 10year old L-49 guava plants during the year 2014-2015 at KRC college of Horticulture, Arabhavi (Karnataka). Pruning at $10-20 \mathrm{~cm}$ of shoot length proved to be most effective in getting very good quality fruits whereas pruning combined with bio regulators like NAA, Ethrel and Urea found significantly effective on quality parameter as compared to control combination of pruning and ethrel treated $\left(\mathrm{P}_{2} \mathrm{~T}_{4}\right)$. Plants recorded maximum TSS, TSS: acid ratio and minimum titratable acidity. Combination of pruning and urea treated $\left(\mathrm{P}_{2} \mathrm{~T}_{3}\right)$ plants recorded highest percentage of reducing non reducing and total sugars, highest ascorbic acid and pectin content was recorded in pruned plants with 250 ppm NAA treatment $\left(\mathrm{P}_{2} \mathrm{~T}_{2}\right)$ and highest total phenol was recorded in combination of pruning and ethrel treatment $\left(\mathrm{P}_{2} \mathrm{~T}_{4}\right)$. Skin color, color and appearance was not significantly affected by pruning and bio regulators but texture, taste and flavour, overall acceptability was significantly higher than control.

\section{Introduction}

Guava (Psidium guajava L.) is one of the most important tropical as well as subtropical fruit crops of the world and is a potential crop of India belongs to the family Myrateace; it was originated in tropical America and then distributed throughout the world. In India, it is ranked as fifth major fruit after Mango, Banana, Citrus and Apple (Anonymous, 2004). It is usually known as the poor man's fruit or apple of the tropics. Guava is one of the attractive fruit in appearance, shape, fragrance and nutrition. Depending on cultivars, it contains four times more ascorbic

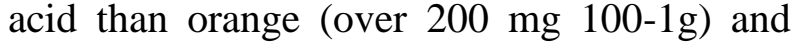
generally a broad low-calorie profile of essential nutrients (Adrees et al., 2010; Hassimotto et al., 2005; Swain and Padhi, 2012). Its seeds provide omega- 3 and omega- 6 polyunsaturated fatty acids and especially high levels of dietary fiber (Anon., 2009). It contains carotenoids and polyphenols which are the major classes of dietary antioxidant pigments among plant foods (Hassimotto et al., 2005; Jimenez-Escrig et al., 2001). Due to their astringent properties, mature guava fruits, leaves, roots and bark are used in local medicines to treat gastroenteritis, asthma, high blood pressure, obesity and diarrhea (Joseph 
and Priya, 2011). Its cultivation in India isas early as 17th century (Mitra and Bose, 1990). In subtropical climate, three distinct periods of flowering and fruiting are found in the guava. These three distinct periods are Ambebahar (February to March flowering and fruit ripens in July- August), Mrigbahar (June to July flowering and fruit ripens in October to December) and Hasta bahar (October to November flowering and fruit ripens in February to April) (Shukla et al., 2008). The heaviest flowering has always been obtained in summer season. Because the food reserved is already exhausted in flowering and vegetative growth during summer, the rainy season flowering for the winter crop is always less but winter season crop is preferred because of its superior quality as compared to monsoon crop (Pandey et al., 1980). Moreover, rainy season fruits are small in size, inferior in quality due to temperature and humidity leads to highly susceptible to pest and disease infestation. The best remedy to this problem would be to eliminate the rainy season crop and thereby to induce a good winter crop. There were earlier works in this line by avoiding monsoon crop through shoot pruning, hand deblossoming, foliar sprays of urea and growth regulators at full bloom and pre bloom stages which correspondingly induce a reasonably good winter season crop (Singh et al., 1992; Lal et al., 2000; Tiwari and Lal, 2007). The present investigation is an attempt to standardize a crop regulation technique with $10-20 \mathrm{~cm}$ shoot pruning and sprays of different bio regulators at 50\% flowering stage during rainy season crop.

\section{Materials and Methods}

The present investigation was conducted during the year 2014-2015 at Kittur Rani Channamma College of Horticulture, Arabhavi (University of Horticultural Sciences, Bagalkot), Gokak taluk of Belgaum district, Karnataka. The experimental material consisted of ten- year-old uniform trees of guava variety Sardar. The treatment consisted of two pruning levels, i.e. no pruning (P1), pruning $(\mathrm{P} 2)$ and four bio regulators treatment, i.e. control $=\mathrm{T} 1$, NAA $250 \mathrm{ppm}=\mathrm{T} 2$, Urea $15 \%=\mathrm{T} 3$, Ethrel $500 \mathrm{ppm}=\mathrm{T} 4$ and Cycocel $50 \mathrm{ppm}=\mathrm{T} 5$ all treatments were applied as foliar spray at $50 \%$ flowering stage. There were ten treatment combinations each replicated four times in factorial randomized block design. Shoot pruning of current season's growth was done at $10-20 \mathrm{~cm}$ of shoot length. It was performed in the first week of May. The data on physico-chemical parameters of fruits were recorded. Physical and chemical parameters of fruits were determined using to average size fruits collected randomly from each replication. The TSS (0 Brix) was determined with the help of a hand refractometer. Ascorbic acid and acidity were analyzed by using the standard method recommended by A.O.A.C. (1990). The TSS: Acid ratio was calculated by dividing TSS by the corresponding Titratable acidity value. Total sugars and reducing sugars content were determined by using DNSA method (Miller, 1972), non-reducing sugar was obtained by subtracting reducing sugar from the amount of total sugar and multiplying the resultant by factor 0.95 as given below (Somogyi, 1952). Pectin content was determined in fruit tissue calcium pectate method (Ranganna, 1977). Phenols were estimated as per the Folin Ciocatteau Reagent (FCR) method (Bray and Thorpe, 1954) and expressed as mg per $100 \mathrm{~g}$. Organoleptic evaluation by 10 panelists was carried out using the nine-point hedonic scale described by Peryam and Pilgrim (1957), Statistical analysis was performed using web agri stat package (WASP) Version 2.0 (Jangam and Thali, 2010).

\section{Results and Discussion}

The results obtained from the present investigation are summarized below: 
Effect of pruning and bio regulator treatment on quality parameters in guava

Even though significant differences were noted for fruit quality parameters, the variations among the treatments were very narrow. The total soluble solids (TSS) of fruits influenced non-significantly and TSS to Acid ratio influenced significantly by pruning and maximum value was recorded in $\mathrm{P}_{2}$ (10.34 and $30.41)$ respectively. These are in the same line with the results recorded by Singh and Singh (2001). Singh and Bal (2006) reported higher TSS in plants pruned at $10-20 \mathrm{~cm}$. Bio regulator treatment had a significant effect on both TSS and TSS to acid ratio values of fruits; the highest value was recorded in $\mathrm{T}_{4}$. The increase in TSS, due to application of ethrel in the present investigation might be because of its action on converting complex substances (starch) into simpler ones (sugars) through higher respiration and carbon assimilation activity (Yadav et al., 2001). The results are in line with the findings of Jain and Dashora (2010), Brar et al., (2012) in guava. Their interaction showed non-significant difference for TSS but significant differences for TSS to acid ratio whereas highest value for both the parameter in $\mathrm{P}_{2} \mathrm{~T}_{4}$ (13.00 and 44.10) respectively (Table 1 and Fig. 1).

The trend of results of present investigations with respect to titratable acidity as influenced by pruning showed significant differences. The interpretation of results indicated that the titratable acidity was considerably high $(0.40 \%)$ in unpruned plants compared to pruned plants. These findings are agreement with Singh and Bal (2006) who reported lowest acidity in pruned plants at $6 \times 5 \mathrm{~m}$ spacing. With respect to bio regulator treatment, there was a significant effect observed. Maximum titratable acidity of 0.45 $\%$ was recorded in $\mathrm{T}_{1}$. The interaction effect revealed significant differences for titratable acidity, High values for titratable acidity
(0.48) was recorded in $\mathrm{P}_{1} \mathrm{~T}_{1}$ treatment combination. Similarly, Mohammod et al., (2006), Brar et al., (2012), Jain and Dashora (2010) also reported maximum acidity in control.

The data pertaining to the reducing, nonreducing and total sugar as influenced by pruning revealed significant differences. Plants under gone pruning have recorded maximum values for reducing, non-reducing and total sugar $(4.36 \%, 3.28 \%$ and $7.63 \%$ respectively). These results are in close conformity with the findings of Ali et al., (2014) and Lakpathi et al., (2013). The interpretation of data related to bio regulator treatment on reducing, non-reducing and total sugar was found to be significantly higher in plants that were treated with urea. This might be due to the fact that nitrogen promotes hydrolysis of starch into sugars and application of foliar urea might increase the concentration of polyamines in the plant leaf tissues, which help in attracting more minerals and assimilates into the fruit tissues, there by increases the TSS. Kundu and Mitra (1997) and Singh et al., (2002) also observed the similar results. These results are in close conformity with the findings of Jat and Kacha (2014), Mohammed et al., (2006) and Dwivedi et al., (1990). Improvement in the quality of fruit by urea spray was observed by Rajput et al., (1986). Interactions revealed non-significant differences, although the plants pruned and sprayed with urea recorded maximum (5.34, 4.43 and 9.77) reducing, nonreducing and total sugars respectively (Table 2).

The ascorbic acid content also recorded significant difference with respect to time of pruning. Maximum ascorbic acid (191.84 $\mathrm{mg} / 100 \mathrm{~g}$ ) was recorded in $\mathrm{P}_{2}$. These results are supported by Singh and Reddy (1997), Singh and Dhaliwal (2004), Dhaliwal and Kaur (2003), Singh and Singh (2001). 
Plate.1 Organoleptic evaluation of guava fruits

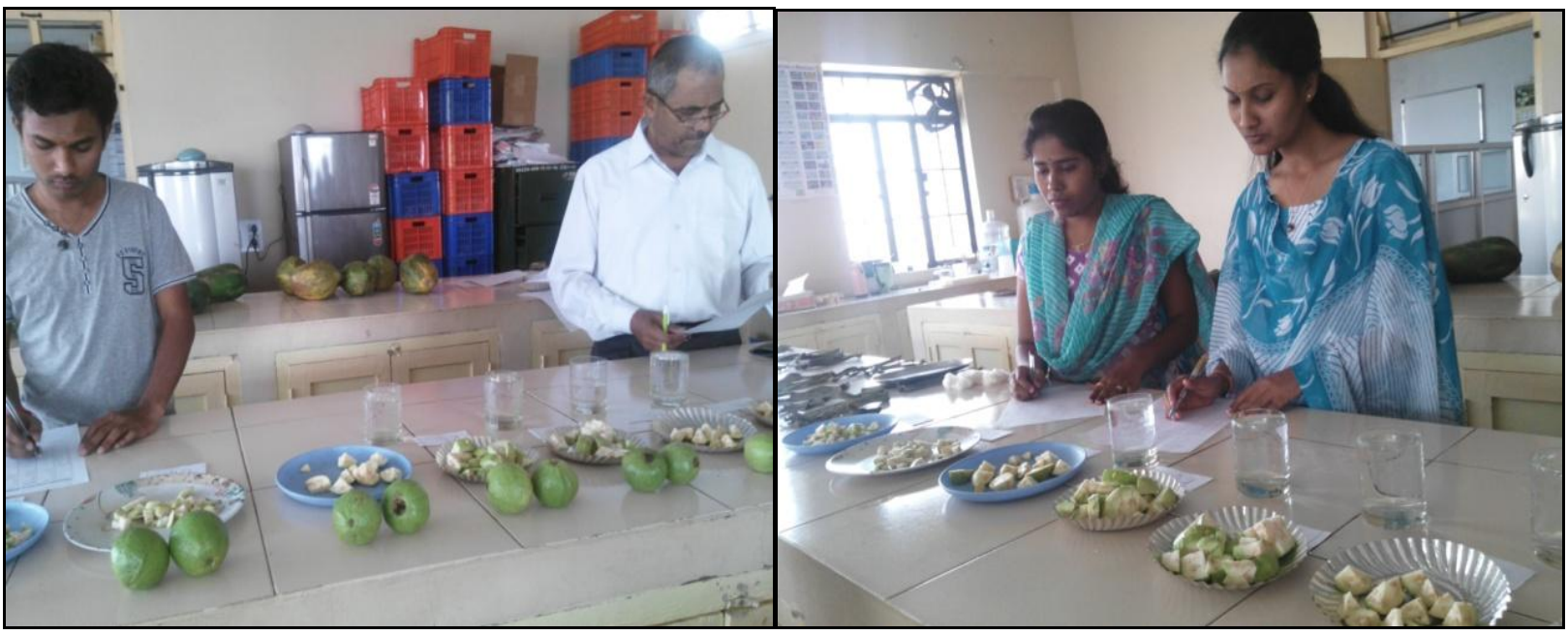

Fig.1 Effect of pruning and bio regulators on quality parameters of guava

\section{Quality Parameters}

12

10

Reducing

sugars (\%)

8

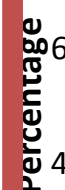

reducing

sugars (\%)

Total

sugars $(\%)$

P1- No pruning

P2- Pruning

T4- Ethrel 500ppm T5- CCC 50ppm

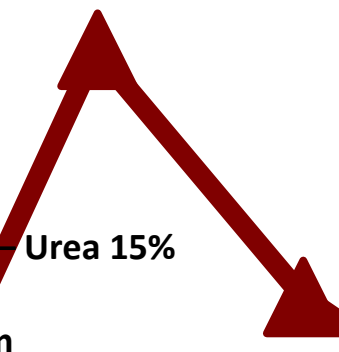


Table.1 Effect of pruning and bio regulators on TSS and titratable acidity of guava fruits

\begin{tabular}{|c|c|c|c|}
\hline Treatments & $\mathrm{TSS}^{\circ} \mathrm{B}$ & $\begin{array}{c}\text { Titratable acidity } \\
(\%)\end{array}$ & $\begin{array}{l}\text { TSS: Acid } \\
\text { Ratio }\end{array}$ \\
\hline \multicolumn{4}{|l|}{ Pruning } \\
\hline $\mathbf{P}_{1}$ (No pruning) & 10.22 & 0.40 & 26.00 \\
\hline $\mathbf{P}_{2}$ (Pruning) & 10.34 & 0.36 & 30.41 \\
\hline S.Em \pm & 0.19 & 0.01 & 1.21 \\
\hline CD at $5 \%$ & NS & 0.03 & 3.5 \\
\hline \multicolumn{4}{|c|}{ Bio regulator treatments } \\
\hline $\mathrm{T}_{1}$ (Control) & 09.45 & 0.45 & 21.31 \\
\hline $\mathbf{T}_{2}$ (NAA 250 ppm) & 10.59 & 0.38 & 27.63 \\
\hline $\mathrm{T}_{3}($ Urea $15 \%)$ & 10.00 & 0.33 & 30.68 \\
\hline $\mathrm{T}_{4}($ Ethrel 500 ppm) & 11.10 & 0.34 & 35.61 \\
\hline $\mathrm{T}_{5}($ Cycocel 50 ppm $)$ & 10.26 & 0.40 & 25.81 \\
\hline S.Em \pm & 0.30 & 0.02 & 1.91 \\
\hline CD at $5 \%$ & 0.85 & 0.05 & 5.55 \\
\hline \multicolumn{4}{|l|}{ Interactions } \\
\hline $\mathbf{P}_{1} \mathbf{T}_{1}$ & 09.13 & 0.48 & 19.18 \\
\hline $\mathbf{P}_{1} \mathbf{T}_{2}$ & 10.63 & 0.40 & 26.87 \\
\hline $\mathrm{P}_{1} \mathrm{~T}_{3}$ & 10.00 & 0.32 & 31.00 \\
\hline $\mathbf{P}_{1} \mathbf{T}_{4}$ & 10.95 & 0.41 & 27.11 \\
\hline $\mathbf{P}_{1} \mathbf{T}_{5}$ & 10.40 & 0.40 & 25.85 \\
\hline $\mathbf{P}_{2} \mathbf{T}_{1}$ & 10.08 & 0.41 & 23.45 \\
\hline $\mathbf{P}_{2} \mathbf{T}_{2}$ & 12.05 & 0.38 & 28.39 \\
\hline $\mathbf{P}_{2} \mathbf{T}_{3}$ & 10.63 & 0.34 & 30.33 \\
\hline $\mathbf{P}_{2} \mathbf{T}_{4}$ & 13.00 & 0.28 & 44.10 \\
\hline $\mathbf{P}_{2} \mathbf{T}_{5}$ & 11.58 & 0.40 & 25.78 \\
\hline S.Em \pm & 0.41 & 0.02 & 2.70 \\
\hline CD at $5 \%$ & NS & 0.07 & 7.85 \\
\hline CV (\%) & 8.05 & 12.37 & 19.20 \\
\hline
\end{tabular}

Pruning followed at $10-20 \mathrm{~cm}$ of shoot length NS - Non-significant 
Table.2 Effect of pruning and bio regulators on biochemical parameters of guava

\begin{tabular}{|c|c|c|c|}
\hline Treatments & $\begin{array}{c}\text { Total sugars } \\
(\%)\end{array}$ & $\begin{array}{l}\text { Reducing sugars } \\
(\%)\end{array}$ & $\begin{array}{c}\text { Non-reducing } \\
\text { sugars }(\%)\end{array}$ \\
\hline \multicolumn{4}{|l|}{ Pruning } \\
\hline$P_{1}$ (No pruning) & 7.15 & 4.09 & 3.06 \\
\hline $\mathbf{P}_{2}$ (Pruning) & 7.63 & 4.36 & 3.28 \\
\hline S.Em \pm & 0.11 & 0.08 & 0.08 \\
\hline CD at $5 \%$ & 0.31 & 0.23 & 0.22 \\
\hline \multicolumn{4}{|c|}{ Bio regulator treatments } \\
\hline $\mathrm{T}_{1}$ (Control) & 5.51 & 3.14 & 2.37 \\
\hline $\mathrm{T}_{2}$ (NAA 250 ppm) & 6.90 & 4.23 & 2.66 \\
\hline $\mathrm{T}_{3}($ Urea $15 \%)$ & 9.35 & 4.99 & 4.36 \\
\hline $\mathrm{T}_{4}($ Ethrel 500 ppm) & 7.98 & 4.51 & 3.47 \\
\hline $\mathrm{T}_{5}($ Cycocel 50 ppm $)$ & 7.20 & 4.22 & 2.99 \\
\hline S.Em \pm & 0.17 & 0.13 & 0.12 \\
\hline CD at $5 \%$ & 0.49 & 0.37 & 0.35 \\
\hline \multicolumn{4}{|l|}{ Interactions } \\
\hline $\mathbf{P}_{1} \mathbf{T}_{1}$ & 5.30 & 3.03 & 2.27 \\
\hline $\mathbf{P}_{1} \mathbf{T}_{2}$ & 6.68 & 4.16 & 2.52 \\
\hline $\mathbf{P}_{1} \mathbf{T}_{3}$ & 8.94 & 4.65 & 4.30 \\
\hline $\mathbf{P}_{1} \mathbf{T}_{4}$ & 7.77 & 4.46 & 3.31 \\
\hline $\mathbf{P}_{1} \mathbf{T}_{5}$ & 7.06 & 4.15 & 2.91 \\
\hline $\mathbf{P}_{2} \mathbf{T}_{1}$ & 5.73 & 3.26 & 2.47 \\
\hline $\mathbf{P}_{2} \mathbf{T}_{2}$ & 7.13 & 4.32 & 2.81 \\
\hline$P_{2} T_{3}$ & 9.77 & 5.34 & 4.43 \\
\hline $\mathbf{P}_{2} \mathbf{T}_{4}$ & 8.20 & 4.57 & 3.63 \\
\hline $\mathbf{P}_{2} \mathbf{T}_{5}$ & 7.35 & 4.29 & 3.06 \\
\hline S.Em \pm & 0.24 & 0.18 & 0.17 \\
\hline CD at $5 \%$ & NS & NS & NS \\
\hline $\mathrm{CV}(\%)$ & 6.41 & 8.54 & 10.62 \\
\hline
\end{tabular}

Pruning followed at $10-20 \mathrm{~cm}$ of shoot length NS- Non-significant 
Table.3 Effect of pruning and bio regulators on ascorbic acid, total phenol and Pectin content of guava

\begin{tabular}{|c|c|c|c|}
\hline Treatments & $\begin{array}{c}\text { Ascorbic acid } \\
(\mathrm{mg} / \mathbf{1 0 0 g})\end{array}$ & $\begin{array}{l}\text { Total phenol } \\
\text { mg/100g }\end{array}$ & $\begin{array}{c}\text { Pectin content } \\
(\%)\end{array}$ \\
\hline \multicolumn{4}{|l|}{ Pruning } \\
\hline$P_{1}$ (No pruning) & 152.76 & 154.25 & 0.67 \\
\hline $\mathbf{P}_{2}$ (Pruning) & 191.84 & 130.20 & 0.70 \\
\hline S.Em \pm & 5.34 & 2.61 & 0.01 \\
\hline CD at $5 \%$ & 15.50 & 7.58 & 0.02 \\
\hline \multicolumn{4}{|c|}{ Bio regulator treatments } \\
\hline $\mathrm{T}_{1}($ Control $)$ & 136.67 & 137.75 & 0.56 \\
\hline $\mathrm{T}_{2}(\mathrm{NAA} 250 \mathrm{ppm})$ & 205.33 & 132.87 & 0.81 \\
\hline $\mathrm{T}_{3}($ Urea $15 \%)$ & 181.32 & 139.63 & 0.65 \\
\hline $\mathrm{T}_{4}($ Ethrel $500 \mathrm{ppm})$ & 170.62 & 152.62 & 0.67 \\
\hline $\mathrm{T}_{5}($ Cycocel $50 \mathrm{ppm})$ & 167.58 & 148.25 & 0.74 \\
\hline S.Em \pm & 8.45 & 4.13 & 0.01 \\
\hline CD at $5 \%$ & 24.51 & 11.99 & 0.04 \\
\hline \multicolumn{4}{|l|}{ Interactions } \\
\hline $\mathbf{P}_{1} \mathbf{T}_{1}$ & 136.25 & 143.75 & 0.57 \\
\hline $\mathbf{P}_{1} \mathbf{T}_{2}$ & 195.67 & 136.00 & 0.78 \\
\hline $\mathbf{P}_{1} \mathbf{T}_{3}$ & 148.50 & 159.00 & 0.60 \\
\hline $\mathbf{P}_{1} \mathbf{T}_{4}$ & 146.25 & 170.00 & 0.65 \\
\hline $\mathbf{P}_{1} \mathbf{T}_{5}$ & 137.16 & 162.50 & 0.75 \\
\hline $\mathbf{P}_{2} \mathbf{T}_{1}$ & 137.05 & 131.75 & 0.55 \\
\hline $\mathbf{P}_{2} \mathbf{T}_{2}$ & 215.00 & 129.75 & 0.84 \\
\hline $4 P_{2} T_{3}$ & 214.14 & 120.25 & 0.70 \\
\hline $\mathbf{P}_{2} \mathbf{T}_{4}$ & 195.00 & 135.25 & 0.70 \\
\hline$P_{2} T_{5}$ & 198.00 & 134.00 & 0.73 \\
\hline S.Em \pm & 11.95 & 5.84 & 0.02 \\
\hline CD at $5 \%$ & 34.66 & 16.96 & 0.06 \\
\hline CV (\%) & 13.87 & 8.22 & 5.53 \\
\hline
\end{tabular}

Pruning followed at $10-20 \mathrm{~cm}$ of shoot length 
Table.4 Effect of pruning and bio regulators on organoleptic evaluation of guava fruits

\begin{tabular}{|c|c|c|c|c|c|}
\hline Treatments & $\begin{array}{l}\text { Skin } \\
\text { colour }\end{array}$ & $\begin{array}{c}\text { Colour\& } \\
\text { appearance }\end{array}$ & Texture & $\begin{array}{c}\text { Taste } \\
\text { \&flavour }\end{array}$ & $\begin{array}{c}\text { Overall } \\
\text { acceptability }\end{array}$ \\
\hline \multicolumn{6}{|l|}{ Pruning } \\
\hline$P_{1}$ (No pruning) & 6.67 & 7.03 & 7.02 & 6.73 & 6.78 \\
\hline $\mathbf{P}_{2}$ (Pruning) & 7.54 & 7.98 & 7.83 & 7.46 & 7.53 \\
\hline S.Em \pm & 0.41 & 0.30 & 0.20 & 0.20 & 0.17 \\
\hline CD at $5 \%$ & NS & 0.93 & 0.62 & 0.62 & 0.53 \\
\hline \multicolumn{6}{|c|}{ Bio regulator treatments } \\
\hline $\mathrm{T}_{1}($ Control $)$ & 7.06 & 7.48 & 6.91 & 6.55 & 6.50 \\
\hline$T_{2}$ (NAA $\left.250 \mathrm{ppm}\right)$ & 7.05 & 8.03 & 7.11 & 7.30 & 7.74 \\
\hline $\mathrm{T}_{3}($ Urea 15\%) & 7.08 & 7.13 & 6.19 & 6.30 & 6.70 \\
\hline $\mathrm{T}_{4}($ Ethrel $500 \mathrm{ppm})$ & 7.00 & 7.30 & 8.63 & 7.39 & 6.75 \\
\hline $\mathrm{T}_{5}($ Cycocel $50 \mathrm{ppm})$ & 7.33 & 7.58 & 8.28 & 7.93 & 8.08 \\
\hline S.Em \pm & 0.64 & 0.48 & 0.32 & 0.32 & 0.27 \\
\hline CD at $5 \%$ & NS & NS & 0.98 & 0.98 & 0.84 \\
\hline \multicolumn{6}{|l|}{ Interactions } \\
\hline$P_{1} T_{1}$ & 6.25 & 7.00 & 6.25 & 6.58 & 6.00 \\
\hline $\overrightarrow{P_{1} \mathbf{T}_{2}}$ & 6.00 & 7.25 & 6.00 & 6.10 & 6.58 \\
\hline$\overline{P_{1} \mathbf{T}_{3}}$ & 7.15 & 6.50 & 5.55 & 6.58 & 6.83 \\
\hline $\mathbf{P}_{1} \mathbf{T}_{4}$ & 6.00 & 6.80 & 8.75 & 6.53 & 6.50 \\
\hline$P_{1} T_{5}$ & 7.65 & 7.58 & 8.55 & 7.85 & 8.00 \\
\hline$P_{2} T_{1}$ & 7.60 & 7.95 & 7.58 & 6.53 & 7.00 \\
\hline $\mathbf{P}_{2} \mathbf{T}_{2}$ & 8.10 & 8.80 & 8.23 & 8.50 & 8.90 \\
\hline $\mathbf{P}_{2} \mathbf{T}_{3}$ & 7.00 & 7.75 & 6.83 & 6.03 & 6.58 \\
\hline $\mathbf{P}_{2} \mathbf{T}_{4}$ & 8.00 & 7.80 & 8.50 & 8.25 & 7.00 \\
\hline $\mathbf{P}_{2} \mathbf{T}_{5}$ & 7.00 & 7.58 & 8.00 & 8.00 & 8.15 \\
\hline S.Em \pm & 0.91 & 0.68 & 0.45 & 0.45 & 0.39 \\
\hline CD at $5 \%$ & NS & NS & 1.38 & 1.39 & 1.19 \\
\hline CV $(\%)$ & 27.20 & 19.27 & 12.77 & 12.06 & 11.43 \\
\hline
\end{tabular}

Pruning followed at $10-20 \mathrm{~cm}$ of shoot length

NS - Non-significant

Significant variation was found in ascorbic acid content among the bio regulators and interaction (Table 3). Ascorbic acid content recorded higher $(205 \mathrm{mg} / 100 \mathrm{~g})$ in fruits collected from NAA treated plants. Interaction revealed significantly high values for ascorbic acid content in fruits collected from plants under $\mathrm{P}_{2} \mathrm{~T}_{2}$ treatment. The results are in line with the findings of Jain and Dashora (2010) in guava and results are contrary with findings of Mohammed et al.,

(2006) who reported higher ascorbic acid in urea $15 \%$.

The maximum total phenol as influenced by pruning was observed in $\mathrm{P}_{1} \quad$ (154.25). Significantly maximum values for total phenol (152.62) as influenced by bio regulator recorded in ethrel treatment. Among the interaction, the maximum value for total phenol (170) was observed with $\mathrm{P}_{1} \mathrm{~T}_{4}$ treatment combination. 
The data related to pectin content by pruning highlighted significant effect. Maximum pectin content was recorded in $\mathrm{P}_{2}(0.70)$. The pectin content as influenced by bio regulator treatment recorded higher values in plants sprayed with NAA (Table 3). The data on interaction highlighted higher values for pectin content in the treatment combination of $\mathrm{P}_{2} \mathrm{~T}_{2}$ (0.84). The results are in line with the findings of Jain and Dashora (2010), Dubey et al., (2002) in guava. On the contrary Mohammed et al., (2006) and Agnihotri et al., (2013) reported high pectin in urea 15\% treatment.

Effect of pruning and bio regulator treatment on organoleptic evaluation in guava (Table 4 and Plate 1)

The trend of results of present investigation with respect to organoleptic properties as influenced by pruning showed significant differences with respect to colour and appearance of pulp, taste and flavor, texture, and overall acceptability. While for skin colour, non- significant difference was observed (Plate 5). The interpretation of results indicated that all the above mentioned organoleptic properties were considerably high in pruned plants compared to unpruned plants. These findings are agreement with Singh and Bal (2006) who reported more palatability rating in $10-20 \mathrm{~cm}$ pruned trees compared to un pruned trees.

With respect to bio regulator treatment, significant difference was observed in case of taste and flavour, texture and overall acceptability. Maximum texture score of 8.63 was recorded in $\mathrm{T}_{4}$, the results obtained are in line with those findings of Jain and Dashora (2010), Singh and Bal (2006) and Brar et al., (2012) in guava who obtained maximum palatability rating of guava fruits with ethrel $1000 \mathrm{ppm}$ (8.01) followed by ethrel $500 \mathrm{ppm}$ (8.09). Whereas highest score for taste and flavor (7.93) was observed in $\mathrm{T}_{5}$ then overall acceptability score was also high (8.08) in $\mathrm{T}_{5}$. Non-significant difference was observed in bio regulator treatment with respect to skin colour and pulp colour and appearance.

The interaction effect revealed non-significant differences for skin colour and pulp colour and appearance, while significant difference was observed for taste and flavor, texture and overall acceptability. A high value for texture (8.75) was recorded in $\mathrm{P}_{1} \mathrm{~T}_{4}$ treatment combination. These results are in close conformity with the findings of Singh and Bal (2006), Jain and Dashora (2010). Similarly, maximum score for taste and flavor and overall acceptability was noticed in the $\mathrm{P}_{2} \mathrm{~T}_{2}$ combination.

\section{References}

A.O.A.C. 1990. Official methods of analysis. Association of Analytical Chemists, 15th Ed. Washington, pp. 573.

Adrees, M., M. Younis, M. Farooq and K. Hussain. 2010. Nutritional quality evaluation of different guava varieties. Pak. J. Agri. Sci., 47: 1-4.

Agnihotri, A., Tiwari, R. and Singh, O. P. (2013) Effect of crop regulators on growth, yield and quality of guava. Annals of Plant and Soil Res., 15 (1): 54-57.

Ali, Sahar, F. and Abdel-Hameed, A. A., 2014, Effect of pruning on yield and fruit quality of guava trees. J. Agri. Veterinary Sci. 7(12): 41-44.

Anonymous, 2004. Economic Survey, 200304 pp. 157.

Anonymous. 2009. Tropical Guava Fruit Facts.www.crfg.org/pubs/ff/guava.html. Retrieved at 03/01/2009.

Brar, J. S., Dhaliwal, H. S. and Bal, J. S. (2012) Influence of paclobutrazol and ethephon on fruit quality of 'Allahabad 
Safeda' guava. Hort Flora Research Spectrum. 1(2): 135-138.

Bray, H. G. and Thorpe, M. U., 1954, Analysis of phenolic compounds of interest in metabolism. Meth. Biochem. Anal., 9:27-52.

Dhaliwal, G. S. and Kaur, R., 2003, Effect of time and pruning intensity on age of bearing shoot and fruit quality of Sardar guava. Haryana J. Hort. Sci. 32(1\&2): 21-24.

Dubey, A. K., Singh, D. B. and Dubey, N., 2002, Crop regulation in guava cv. Allahabad safeda. Prog. Hort., 34 (2): 200-203.

Dwivedi, R., Pathak, R. K. and Pandey, S. D., 1990, Effect of various concentrations of urea on crop regulation in guava (Psidium guajava L.) cv. Sardar. Prog. Hort., 22 (1-4): 134-139.

Hassimotto, N.M., M.I. Genovase and F.M. Lajolo. 2005. Antioxidant activity of dietary fruits, vegetables, and commercial frozen fruit pulps. J. Agri. Food Chem., 53:2928-2935.

Jain M. C. and Dashora L. K., 2010, Effect of different plant bio regulators in relation to fruit quality and yield of Guava (Psidium guajava L.) cv. Sardar. Prog. Hort., 42 (1): 50-53.

Jangam, A. K. and Thali, P., 2011, ICAR Research complex for Goa, Ela, old goa, (India)-403402.

Jat, G. and Kacha, H. L., 2014, Response of guava to foliar application of urea and zinc on fruit set, yield and quality. J. Agri.Search, 1 (2): 86-91.

Jimenez-Escrig, A., M. Rincon, R. Pulido and F. Saura-Calixto. 2001. Guava fruit (Psidium guajava L.) as a new source of antioxidant dietary fiber. J. Agri. Food Chem., 49: 5489-5493.

Joseph, B. and M. Priya. 2011. Review on nutritional, medicinal and pharmacological properties of guava
(Psidium guajava linn.). Int. J. Pharma BioSci. 2: 53-69.

Kundu, S. and Mitra S. K. (1997) Regulation of cropping in guava. Indian J. Hort., 54 (2): 139-145.

Lakpathi, G., Rajkumar, M. and Chandrasekhar, R., 2013, Effect of pruning intensities and fruit load on growth, yield and quality of guava (Psidium guajava L.) cv. Allahabad Safeda under high density planting. Int. J. Curr. Res., 9(12): 4083-4090.

Lal, S., Tiwari, J.P. and Misra, K.K. 2000. Effect of plant spacing and pruning intensity on fruit yield and quality of guava. Indian J. Hort. 37: 234-238.

Miller, G. L., 1972, Use of dinitro salicylic acid reagent for determination of reducing sugar. Ann. Chem., 31: 426428.

Mitra, S.K. and Bose, T. K. 1990. Guava in fruits. Tropical and subtropical (Eds. Bose and Mitra). Nava Prakash, Calcutta pp 280-303.

Mohammed, S. and Sharma, J. R., Ranjeet K., Raj Pal, Singh, S. (2006) Effect of different chemicals on cropping pattern, and quality of guava cv. Sardar. Haryana J. Hort. Sci. 35 (3/4): 226-227.

Pandey, R.M., Lal, S. and Kaul, G.L. 1980. Effect of chemicals and thinning on regulation of crop in guava. Indian $J$. Hort. 37: 234-238.

Peryam, D. R. and Pilgrim, F. J., 1957, Hedonic scale method of measuring food preferences. Food Technol., 11: 914.

Rajput, C. B. S., Singh Gorakh and Mishra, J. S, 1986, Crop regulation in guava by urea sprays. Indian J. Hort., 43 (3 and 4):191-193.

Ranganna, S., 1977, Estimation of pectic substances as calcium pectate. Hand book of analysis and quality control for fruits and vegetable products. Tata Mc Graw Hill Pub. Co. Delhi: 31. 
Shukla, A.K.; Kaushik, R.A.; Pandey, D. and Sarolia, D.K. (2008) In: Guava. Published by Maharana Pratap University of Agriculture and technology, Udaipur, pp: 7.

Singh, A. K. and Singh, G. (2001) Influence of pruning date on fruit quality of guava (Psidium guajava L.). J. Applied Hort., 3(2): 100-102.

Singh, G. and Dhaliwal, G. S., 2004, Effect of different pruning levels on fruit yield and quality of guava (Psidium guajava L.) cv. Sardar. Haryana J. Hort.Sci., 33 (1\&2): 83-84.

Singh, G. and Reddy, Y. T. N., 1997, Regulation of cropping in guava. Indian J. Hort., 54 (1): 44-49.

Singh, G., Singh, A. K., Rajan, S. and Bhriguvanshi, S. R., 2002, Strategy for crop regulation in guava (Psidium guajava L.) through foliar urea sprays and its effect on different $\mathrm{N}$-forms in leaves.J. Appl. Hort., 4 (2):93-98.

Singh, H. J. and Bal, J. S. (2006) Effect of pruning and growth regulators on physico-chemical characters of guava during rainy season planted at different spacing. Int. J. Agri. Sci., 2 (2):533-537.
Singh, H. J. and Bal, J. S., 2006, Effect of pruning and growth regulators on physico-chemical characters of guava during rainy season planted at different spacing. Int. J. Agri. Sci., 2 (2):533-537.

Singh, Raghbir, Singh, S.N., Gupta M.R., Dhaliwal, G.S. and Kalra, S.K. 1992. Studies on winter cropping in guava cv. Allahabad Safeda. Indian J. Hort. 49: 127-133.

Somogyi, M. S., 1952, Notes on sugar determination. J. Boil., Chemistry, 200: 245.

Swain, S.C. and S.K. Padhi. 2012. Changes in growth characters and nutrient acquisition of guava (Psidium guajava L.) in response to coal ash. Pak. J. Agri. Sci., 49: 261-265.

Tiwari, J. P. and Lal, S. 2007. Effect of NAA, Flower bud thinning and pruning on crop regulation in guava (Psidium guajava L.) cv. Sardar. Proc. Ist IS on Guava, ISHS, Acta Hort. 735: 311-314.

Yadav, S. J., Bhatia, S. K., Godara, R.K. and Rana, G. S., 2001, Effect of growth regulators on the yield and quality of winter season guava cv. L-49. Haryana J. Hort. Sci., 30 (1-2): 1-2.

\section{How to cite this article:}

Shweta Hiremath, S.I. Athani, Archana and Kashinath Patil. 2018. Studies on Effect of Crop Regulation Practices on Physico-Chemical Attributes and Organoleptic Evaluation of Guava Variety Sardar. Int.J.Curr.Microbiol.App.Sci. 7(08): 4306-4314. doi: https://doi.org/10.20546/ijcmas.2018.708.451 